\title{
Editorial
}

\section{MANDATORY RETIREMENT}

\section{A.J. McClean*}

The Canadian Charter of Rights and Freedoms, with the exception of section 15 (the equality section) came into effect in 1982; section 15 came into effect in 1985. The adoption of the Charter brought about a fundamental change in the way in which Canadian society will settle, in the legal arena at least, issues, both great and small, on which public opinion may be divided.

Before 1982 one could say that, with a few limitations, between them Parliament and the Legislatures had the power to enact whatever laws they saw fit. The major constitutional question which the courts had to deal with was whether Parliament or one of the Legislatures had overstepped the powers conferred on it by the British North America Act, 1867, now the Constitution Act, 1867. But, in general terms, if one body had not the legal authority to deal with a particular issue, the other had. The courts had no authority to control the substance of legislation, given that the type of legislation under consideration was within the constitutional competence of the enacting body.

The 1867 division of powers remains, but the Charter has put a substantive restraint on both Parliament and Legislature. Legislation passed by either one, even if within its competence under the Constitution Act, 1867, may be held invalid by the courts if the legislation is judged to be incompatible with the Charter. Equally, a court may by virtue of the Charter control the activities of government. How far the Charter applies directly to the activities of the individuals is, we shall see, to some extent still in dispute.

The fundamental nature of the change is thus clear. Parliament, let us say, could enact a piece of legislation, perhaps after long public discussion, Royal Commission and parliamentary debate. The legislation might fall clearly within the competence of Parliament, under the Constitution Act, 1867. The courts could nonetheless decide the legislation is invalid as contravening the provisions of the Charter. By virtue of their powers of interpretation of the Charter, the courts have the authority to make final decisions on any piece of legislation, be it of minor or of major public significance. The one exception to this is that Parliament or a legislature could take a piece of legislation out from under some of the provisions of the Charter by invoking the non obstante section, section 33 .

\footnotetext{
*A.J. McClean, Professor of Law and Associate Vice-President (Academic), University of British Columbia.
} 
Mandatory retirement is one of the large number of controversial issues which are now being looked at fresh in light of the Charter. At a time, the date of retirement was something to be settled as a matter of agreement between employee and employer, either on an individual basis or by collective agreement. In many. occupations, it was the aim of employees to secure relatively early retirement dates, an objective which, if it were to be really advantageous, had to be accompanied by adequate pension benefits. In addition, in many jurisdictions legislation provided for mandatory retirement at specified ages in certain types of employment; often, for example, for those employed in the civil service.

Before the advent of the Charter, Parliament and the provincial Legislatures, each acting within its constitutional sphere of authority, had also enacted human rights legislation. In respect to age discrimination in employment that legislation falls into two categories.

First, the Federal legislation and the legislation in Alberta, Manitoba, New Brunswick and Quebec simply prohibit discrimination in employment on the ground of age, all ages apparently being encompassed by the legislation. Under such legislation it would seem that a mandatory retirement provision based on age alone would be invalid, and that is now clearly settled law in Manitoba. Second, legislation in British Columbia, Newfoundland, Nova Scotia, Ontario and Saskatchewan also prohibits discrimination in employment on the ground of age, but restricts the ages at which the protection operates. In all of these provinces, at the upper end of the age scale, the legislation does not apply to protect those aged 65 or over. In effect, this legislation accommodates itself to the common practice of providing for mandatory retirement at the age of 65 .

Not surprisingly, it was in two of these provinces, British Columbia and Ontario that mandatory retirement schemes were challenged. In each province the litigation involved faculty members who sought to have the mandatory retirement policies of their universities declared invalid. In each case, the challenges to mandatory retirement were based upon an alleged violation of section 15 of the Charter, which guarantees equality under the law and the right not to be discriminated against on, amongst other grounds, that of age. In dealing with these challenges, the courts had to consider three questions:

(1) Does the Charter, and therefore section 15, apply directly to universities?

(2) Does section 15 of the Charter invalidate provisions in human rights legislation which excludes those who are age 65 and over from protection against discrimination in respect to employment?

(3) If there is a violation of section 15, may nonetheless the practice of mandatory retirement be saved by reference to section 1 of the Charter?

The direct application of the Charter to universities turns primarily on the interpretation of section 32. That section states that the Charter applies to the Parliament and government of Canada, and to the legislatures and the governments of the provinces. It has been argued that that section is not an exclusive statement of the application of the Charter, and that, as the supreme law of Canada, the Charter is of universal application, controlling the activities of individuals and 
corporations as well as the activities of legislatures and governments. In general, the courts have rejected this argument, and did so in the mandatory retirement litigation. Section 32, it was decided, states the exclusive scope of the application of the Charter. It applies therefore only to Parliament, legislatures and government.

Universities are obviously not Parliament or legislature; are they government? One might try to answer that question in one of two ways, or on a combination of two ways. First, one might ask if the universities are controlled by government to such an extent that they really are arms of government. On the one hand, universities are generally created by legislation, are, in large measure, supported by grants from government, and government may exercise some modicum of control over some of their activities. However, as was noted in the two decisions, universities have a large degree of independence with respect to their mode of operation, with respect to the use they may make of government's grants, with respect to curriculum, the setting of students fees, the employment of faculty and other staff. It was decided therefore that the universities operated independently of government and that consequently the Charter did not apply directly to them.

Second, either as an alternate or as a supplementary argument, one might ask if the universities do what governments do or should do. In other words, the test would not be whether the universities are controlled by government, but whether the universities, however they are established as a matter of form, are carrying out government type activities. That, of course, raises a normative question on which philosophers and political scientists may differ, and on which as a matter of fact there is no uniformity from country to country or from age to age. In the British Columbia case, it was decided that the universities were not carrying out a government's functions; although, by way of contrast, it is interesting to note that in an accompanying decision it was held that the Vancouver General Hospital was.

If, however, it be assumed that the Charter, and therefore section 15, do not apply directly to universities, then one must consider the second question of what can be called the possible indirect application of the section. As we have seen, the human rights legislation in the provinces we are concerned with prohibits discrimination in employment on the ground of age, but that the legislation does not apply to those who are 65 and over. Section 15 prohibits discrimination on the ground of age. It follows, it may be argued, that the human rights legislation is discriminatory in protecting those under but not those over 65 , and any provisions depriving those over 65 of protection should therefore be stricken down as being incompatible with section 15 . The legislation would then prohibit discrimination on the ground of age simpliciter and would apply to all employers in the province, including the universities. Mandatory retirement would therefore, as a general proposition, be invalid.

In both Ontario and British Columbia, the courts rejected that argument, but on somewhat different reasoning.

In British Columbia, it was decided that it was too simplistic to argue that any drawing of distinctions is in itself discrimination. Legislation by its very nature is almost compelled to draw distinctions. Discrimination is not therefore the drawing 
of distinctions, but the drawing of distinctions which are unfair, unreasonable or unjustifiable. Mandatory retirement, it was admitted by the courts, could be unfair in that it forced the retirement at 65 of those who were capable of continuing to work, and that it could be disadvantageous to them. But on the other hand, there were many considerations that pointed the other way. Many of our social and economic institutions are predicated on mandatory retirement at 65. Mandatory retirement carried with it various benefits - it created employment for the young, it helped the universities in difficult financial times, it aided in bringing about the dignified termination of employment of those whose continuing competence might have been in doubt. And it was a well understood term of the contract of employment and it was coupled with a reasonable pension arrangement. On balance, therefore, the court decided that at least the retirement scheme with which it was concerned was not unfair, unreasonable or unjustifiable. For the human rights legislation to tolerate retirement in such circumstances did not constitute a violation of section 15 of the Charter.

The Ontario decision took a different approach. It decided that a scheme of mandatory retirement did discriminate between employee and employee on no other grounds than that of age. It did so in an arbitrary way, taking no account of the individual characteristics of those affected, but rather appeared to be based on a stereotype assumption about older workers.

Having decided that the Ontario legislation, so far as it permitted mandatory retirement at age 65 , was invalidated by section 15 , the Ontario court then had to proceed to consider the third question, the effect of section 1 of the Charter. Section 1 provides that the rights and freedoms protected by the Charter are subject to "such reasonable limits prescribed by law as can be demonstrably justified in a free and democratic society".

In approaching section 1, the Ontario Court followed the approach set out in earlier decisions of the Supreme Court of Canada. It first asked whether permitting mandatory retirement at age 65 was in furtherance of objectives of such importance to society that it could be permitted to override one of the rights protected by the Charter. The court decided that in enacting its legislation, the Ontario Legislature did not abolish mandatory retirement because of a concern that total abolition might have adverse effect on such things as pension plans and prospective employment for the young. With respect to universities, the need for fresh blood in areas of constant change was noted as being an area of particular significance. The court decided that these were valid legislative objectives which could justify the limitation on the general prohibition against discrimination on the basis of age. It may also be worth pointing out, however, that the court did not accept that the easing out of those whose competence allegedly were diminishing was an objective that could justify a mandatory retirement scheme.

Having decided that mandatory retirement schemes had objectives significantly important to justify an overriding of a protected Charter right, the court then had to decide if the means adopted by the Legislature to achieve that objective were justifiable. It concluded that while a law mandating retirement at the age of 65 was 
in some degree arbitrary, it had a rational relationship to the objectives of protecting the integrity of pension schemes and providing employment opportunities for the young. Moreover, mandatory retirement did not impinge to an excessive extent on the right not to be discriminated against on the basis of age, particularly in light of the fact that mandatory retirement was a widespread phenomenon and that many people had expectations based upon it. Nor, in the opinion of the court, did mandatory retirement at age 65 go further than was necessary to protect the legitimate objectives the government had in mind.

The end result was that both the British Columbia and the Ontario Courts decided that the mandatory retirement schemes in issue before them were not invalidated by the Charter. The litigation is not, however, over. Both cases have been appealed and both are likely to find their way eventually to the Supreme Court of Canada. Whatever the eventual outcome may be the cases obviously give rise to a wide range of issues. By way of conclusion, some comment may be made on two of them.

First, the cases illustrate neatly the issue of how far a shift in power has been brought about by the Charter. Before its enactment, the courts would have been bound by the terms of the human rights legislation they were considering, and their role would have been to see that the legislation was properly applied. They now have the authority to test the validity of the legislation against the rights and freedoms set out in the Charter. In many areas, particularly in criminal law and in controlling the activities of government bureaucracies, the courts have been quick to find violations of the Charter, and to strike down legislation and regulation or to control bureaucratic conduct.

What is interesting about the two decisions on mandatory retirement is that they show some signs of judicial restraint, of the disposition, despite the Charter, to defer to legislative policies. Indeed, the British Columbia case made the point directly. The new Constitution, the court said, did not empower the courts to promote or control economic or social change. It will be recalled that there was considerable debate about whether there should be a provision in the Charter protecting private property. One of the arguments against such a provision was that in the United States at least, such a clause had at a time been used to strike down a wide range of social welfare and employment related legislation. It may be, therefore, that while Canadian courts will be more than willing to use the Charter to protect the individuals against the State, they will still leave economic and social policies to Parliament and the Legislatures.

Second, looking particularly at universities, if in the end it should be decided that mandatory retirement is indeed unconstitutional, universities and faculty members, along with other employers and employees, will have to adjust to that new environment. The degree of adjustment will depend in some measure on the number of people who continue working after 65 , and on how long they continue to work.

It would seem that it is as yet too early to draw any clear inferences from the experience of those jurisdictions where mandatory retirement has been abolished. 
Nonetheless, the indications are that there will be a significant number of people staying at least through their late sixties.

If that be so it could, at least in the short term, pose problems. Faculty members continuing to work after 65 will add to universities salary bills and could cause complication with respect to pension plans and other economic benefits. The influx of new faculty members could be delayed, unless there is also a flow of new money for salaries. Questions will no doubt be raised about the tenure system, for it could be argued that, without mandatory retirement, it will become a system of tenure for life, or until voluntary retirement.

Universities could react to these challenges in a number of ways. With respect to tenure, it might be possible to establish more rigorous and more regular reviews of performance. But if that were embarked upon on a large scale, and combined with what in many universities are already elaborate and time-consuming procedures for granting a promotion and tenure, one might wonder if there will be time for the academic enterprise itself. It is easy to imagine a whole range of issues, both substantive and procedural, which would have to be grappled with. One, in the context of the Charter, may be noted in passing - would a provision for reviews of performance triggered at a certain age in itself be a violation of the Charter?

Perhaps, rather than moving into reviews of performance on a larger scale than is customary at present, the universities might be better advised to try to adopt practices that in fact accommodate faculty members' different expectations and aims. Some members of faculty may indeed wish to work beyond the age of 65 . On the other hand there are those who would willingly retire before that age if the financial sacrifice is not too great. Equally, there are others who would be willing to change from full-time to part-time status sometime before the traditional retirement age, and perhaps work, on a part-time basis, a few years beyond it. Even if in the end mandatory retirement was not held to be invalid, these are matters which universities ought to, and in many cases are, beginning to look at, and indeed implement. But, for both internal and external reasons, it may not always be easy to make these changes. For example, it would seem that the changes in tax legislation currently under consideration may limit the amounts that may be paid into a pension plan on behalf of those on part-time status, and so make that a less attractive option.

The courts' eventual disposition of the two cases involving mandatory retirement may provide some indication of how far the courts are prepared to use their powers under the Charter in the area of general social and economic concern. And whatever the courts eventually decide, the debate on mandatory retirement may require universities (and other employers) to consider more flexible practices, particularly with respect to those employees who are approaching what has been until now the traditional retirement age. 


\section{LA RETRAITE OBLIGATOIRE}

\section{A.J. McClean*}

La Charte canadienne des droits et libertés est entrée en vigueur en 1982, à l'exception de l'article 15 (les droits à l'égalité) qui n'est entré en vigueur qu'en 1985. Cette Charte a entraîné un changement fondamental de la manière dont la société canadienne règlera, tout au moins dans le domaine légal, les questions plus ou moins importantes sur lesquelles l'opinion publique peut être partagée.

Avant 1982, on pouvait dire qu'à quelques exceptions près, le Parlement et les législatures avaient le pouvoir d'adopter toute loi qui leur convenait. La principale question constitutionnelle apportée devant les tribunaux a été de savoir si le Parlement ou l'une des législatures avait outrepassé les droits que lui avait conférés l'Acte de l'Amérique du Nord britannique de 1867, maintenant appelée Loi constitutionnelle de 1867. Généralement cependant, si l'un des organismes n'avait pas le pouvoir légal de régler une question, l'autre l'avait. Les tribunaux n'avaient aucun contrôle sur la substance de la législation car celle-ci faisait partie des pouvoirs constitutionnels de l'organisme qui la promulguait.

Même si le partage des pouvoirs de 1867 demeure, la Charte entraîne un certain nombre de contraintes pour le Parlement et la législature. Si l'un ou l'autre adopte une législation en vertu des pouvoirs que lui confère la Loi constitutionnelle de 1867 , les tribunaux peuvent invalider cette législation s'ils la jugent incompatible avec la Charte. De même, aux termes de la Charte, un tribunal peut contrôler les activités du gouvernement. Comme nous le verrons. le débat n'est pas clos sur les applications directes de la Charte aux activités des personnes.

Le changement fondamental est clair. Après une longue discussion publique, une commission royale et des débats parlementaires, le Parlement pourrait passer un décret; et aux termes de la Loi constitutionnelle de 1867, la législation pourrait fort bien relever de la compétence du Parlement. Cependant, les tribunaux pourraient décider d'invalider la législation parce qu'elle contrevient aux stipulations de la Charte. En vertu de leurs pouvoirs d'interprétation de la Charte, les tribunaux ont le dernier mot sur tout arrêté, qu'il soit d'importance majeure ou mineure pour le public. La seule façon pour le Parlement ou une législature d'échapper aux contraintes de la Charte serait d'invoquer l'article 33 (sur la dérogation) pour adopter une loi.

La retraite obligatoire constitue l'un des nombreux sujets de controverse qui sont maintenant réétudiés à la lumière de la Charte. Il fut un temps où la date de la retraite faisait l'objet d'une entente entre l'employé et l'employeur, soit individuellement, soit par convention collective. Dans beaucoup de métiers, les employés cherchaient surtout à prendre leur retraite assez tôt, objectif qui, pour être vraiment avantageux, devait être assorti de prestations de retraite adéquates.

*A.J. McClean, professeur de droit et vice-recteur adjoint à l'enseignement et à la recherche, University of British Columbia 
De plus, dans bien des cas, la législation prévoyait la retraite obligatoire à un âge précis pour certains emplois comme souvent, par exemple, dans la fonction civile.

Avant l'avènement de la Charte, le Parlement et les législatures provinciales, agissant conformément à leurs pouvoirs constitutionnels, avaient adopté une législation sur les droits de la personne. Eu égard à la discrimination en vertu de l'âge, cette législation tombe dans deux catégories.

Premièrement, en matière d'emploi, la législation fédérale et celle de l'Alberta, du Manitoba, du Nouveau-Brunswick et du Québec interdisent tout simplement la discrimination fondée sur l'âge; apparemment, la législation inclut tous les âges. Une telle législation annulerait donc les stipulations relatives à la retraite obligatoire fondées sur l'âge seulement. Ceci est maintenant clairement stipulé dans la loi du Manitoba. Deuxièmement, la législation de Colombie-britannique, de Terre-Neuve, de Nouvelle-Ecosse, d'Ontario et de Saskatchewan interdisent aussi la discrimination fondée sur l'âge mais précise les limites d'âges auxquelles la protection s'applique. Dans ces dernières, la loi ne protège pas les personnes âgées de 65 ans et plus. En fait, cette législation reflète la pratique commune de fixer la retraite obligatoire à 65 ans.

Il n'est pas surprenant que ce soit dans deux de ces provinces, la Colombiebritannique et l'Ontario, que la retraite obligatoire ait été contestée. Dans chaque province, le procès impliquait des professeurs qui cherchaient à faire invalider les politiques de retraite obligatoire de leur université. Dans chaque cas, la contestation de la retraite obligatoire reposait sur une allégation de violation de l'article 15 de la Charte qui garantit légalement l'égalité et le droit de ne pas faire l'objet de discrimination du fait, entre autres, de l'âge. L'étude de ces cas a amené les tribunaux à considérer trois questions:

(1) La Charte, et par conséquent l'article 15, s'appliquent-ils aux universités?

(2) L'article 15 de la Charte annule-t-il les stipulations de la législation sur les droits de la personne qui exclut toutes les personnes âgées de 65 ans et plus de la protection contre la discrimination en matière d'emploi?

(3) S'il y a eu violation de l'article 15, est-il possible néanmoins d'instituer la retraite obligatoire en vertu de l'article 1 de la Charte?

L'application directe de la Charte aux universités, repose d'abord sur l'interprétation de l'article 32. Cet article stipule que la Charte s'applique au Parlement et au gouvernement du Canada, et à la législature et au gouvernement de chaque province. On a soutenu que cet article n'énonce pas les applications exclusives de la Charte, et que, en tant que loi suprême du Canada, la Charte s'applique universellement tant au contrôle des activités des individus et des sociétés que des activités des législatures et des gouvernements. En général, les tribunaux ont rejeté cet argument; et ils l'ont rejeté dans les litiges touchant la retraite obligatoire. Il fut décidé que l'article 32 définissait le champ d'application exclusif de la Charte, et qu'en conséquence il s'applique uniquement au Parlement, aux législatures et aux gouvernements.

Il est évident que les universités ne se classent pas dans la catégorie du Parlement ou d'une législature; se rangent-elles dans celle d'un gouvernement? Pour répondre à cette question, on peut choisir deux points de vue différents ou les 
combiner. Premièrement, on peut se demander si le contrôle exercé par le gouvernement sur les universités fait réellement de celles-ci des ramifications gouvernementales. Notons que les universités sont généralement créées par une législation, qu'elles sont dans une large mesure financées par des subventions gouvernementales et que le gouvernement peut exercer un miminum de contrôle sur leurs activités. Cependant, comme on l'a souligné dans les deux décisions, les universités jouissent d'une grande indépendance au niveau de leur fonctionnement, de l'utilisation des subventions gouvernementales, des programmes d'études, du montant des frais de scolarité, de l'engagement du personnel enseignant et non enseignant. Il a donc été décidé que les universités fonctionnaient indépendamment du gouvernement et que par conséquent, la Charte ne s'appliquait pas directement à elles.

Deuxièmement, on peut se demander si les universités ont les mêmes fonctions que les gouvernements ont ou devraient avoir. En d'autres mots, l'enquête ne consisterait pas tant à déterminer si les universités sont contrôlées pas le gouvernement, mais, bien qu'elles soient créées par une loi, si les universités ont des activités de type gouvernemental. Bien sûr, cette remarque soulève une question sur laquelle les philosophes et les spécialistes de la politique peuvent avoir des opinions divergentes, et sur laquelle en fait, il est impossible d'avoir l'unanimité d'un pays à l'autre et d'un âge à l'autre. Dans le cas de la Colombie britannique, on a décidé que les universités n'avaient pas les fonctions d'un gouvernement; par contre, il est intéressant de noter que dans une décision rendue en même temps, on avait soutenu que le Vancouver General Hospital avait les fonctions d'un gouvernement.

Cependant, si on suppose que la Charte, et par conséquent l'article 15 ne s'appliquent pas aux universités, il faut en second lieu considérer ce que l'on peut appeler la possibilité d'application indirecte de l'article 15. Comme nous l'avons $\mathrm{vu}$, la législation des droits de la personne des provinces qui font l'objet de notre propos interdit la discrimination en matière d'emploi du fait de l'âge mais cette législation ne s'applique pas aux personnes âgées de 65 ans et plus. L'article 15 de la Charte interdit la discrimination du fait de l'âge. Il s'ensuit, peut-on soutenir, que la législation provinciale des droits de la personne est discriminatoire parce qu'elle protège les personnes de moins de 65 ans mais pas les plus âgées. Toute stipulation de cette législation qui prive les citoyens de plus de 65 ans de sa protection devrait par conséquent être bannie pour la simple raison qu'elle est incompatible avec l'article 15 de la Charte. La législation interdirait donc la discrimination du fait de l'âge en général et s'appliquerait à tous les employeurs de la province, y compris les universités. La proposition touchant la retraite obligatoire ne serait donc plus valable.

En Ontario et en Colombie britannique, les tribunaux ont réfuté cet argument mais pour des raisons quelque peu différentes.

En Colombie britannique, les tribunaux ont trouvé qu'il était un peu trop simple de soutenir que le fait de faire des distinctions est en soi discriminatoire. De par sa nature, la législation oblige presque à faire des distinctions. La discrimination ne consiste pas à faire des distinctions mais à faire des distinctions injustes, 
déraisonnables ou injustifiables. Les tribunaux ont admis que la retraite obligatoire pouvait être injuste du fait qu'elle obligeait les personnes âgées de 65 ans à prendre leur retraite même si elles étaient capables de continuer à travailler, et que cet état de choses pouvait les désavantager. Mais par ailleurs, beaucoup d'autres considérations faisaient pencher la balance dans l'autre sens. Dans beaucoup de nos institutions sociales et économiques, la retraite est obligatoire à 65 ans; et elle a aussi des avantages - elle crée de l'emploi pour les jeunes, aide les universités à passer les crises financières, permet aux personnes dont la compétence de longue date commence à être mise en doute de partir dignement. De plus, elle est clairement stipulée dans le contrat de travail et est assortie d'une pension raisonnable. Tout bien considéré, le tribunal a décidé que le plan de retraite qui lui avait été soumis était juste, raisonnable et justifiable. La législation provinciale des droits de la personne, en tolérant la retraite dans de telles circonstances, n'enfreint nullement l'article 15 de la Charte.

Le tribunal de l'Ontario a adopté une approche différente. Il a jugé qu 'un plan de retraite obligatoire, sans autre fondement que l'âge, était effectivement discriminatoire. Sa décision, prise de façon arbitraire, ne tenait pas compte des caractéristiques individuelles des personnes concernées mais reposait plutôt sur une idée stéréotypée des travailleurs plus âgés.

Ayant décidé que l'article 15 invalidait la législation ontarienne parce qu'elle autorisait la retraite obligatoire à 65 ans, le tribunal de l'Ontario a alors commencé à étudier la troisième question, à savoir l'effet de l'article 1 de la Charte. L'article 1 stipule que les droits et libertés protégés par la Charte "ne peuvent être restreints que par une règle de droit, dans des limites qui soient raisonnables et dont la justification puisse se démontrer dans le cadre d'une société libre et démocratique."

Dans son étude de l'article 1, la Cour de l'Ontario a suivi le processus adopté antérieurement par la Cour suprême du Canada. Elle a tout d'abord demandé si le fait de permettre la retraite obligatoire à 65 ans visait des objectifs d'une importance telle pour la société qu'il justifiait le mépris d'un des droits protégé par la Charte. La Cour de l'Ontario a jugé qu'en promulguant sa législation, la législature ontarienne n'avait pas aboli la retraite obligatoire par souci des conséquences néfastes que l'abolition totale pourrait entraîner sur les plans de retraite et les perspectives d'emploi pour les jeunes par exemple. Dans le cas des universités, on a noté l'importance du besoin de sang neuf dans les domaines en évolution constante. La Cour a décidé qu'il s'agissait là d'objectifs législatifs valables qui pouvaient justifier de limiter l'interdiction générale de discrimination en fonction de l'âge. Cependant, il peut être également utile de signaler que la Cour n'a pas accepté que le fait d'écarter ceux dont la compétence avait soi-disant diminué constituait un objectif qui pouvait justifier un plan de retraite obligatoire.

Après avoir décidé que les plans de retraite obligatoire correspondaient à des objectifs assez importants pour justifier le mépris d'un droit protégé par la Charte, le tribunal devait alors décider si les moyens adoptés par la législature pour atteindre ces objectifs étaient justifiables. Il a conclu que tandis qu'une loi instituant la retraite obligatoire à 65 ans était quelque peu arbitraire, on pouvait quand même y voir une relation raisonnable avec les objectifs de protection de 
l'intégrité des plans de retraite et de possibilités d'emploi pour les jeunes. De plus, la retraite obligatoire n'empiétait pas excessivement sur le droit de ne pas faire l'objet de discrimination en fonction de l'âge, particulièrement à la lumière du fait que la retraite obligatoire était un phénomène très répandu et que beaucoup de gens avaient des projets qui reposaient sur elle. De l'avis du tribunal, le gouvernement restait dans les limites du raisonnable pour protéger ses objectifs légitimes en appliquant le principe de la retraite obligatoire à 65 ans.

Finalement, les tribunaux de la Colombie britannique et de l'Ontario ont décidé que les plans de retraite obligatoire qui leur étaient soumis n'étaient pas invalidés par la Charte. Le litige n'est cependant pas réglé. Dans les deux cas, il y a eu appel et il est fort probable que ces affaires iront jusqu'en Cour suprême du Canada. En attendant, et quel que soit le résultat, il est évident que ces cas soulèvent toutes sortes de questions. En guise de conclusion, nous en commenterons deux.

Premièrement, les cas étudiés illustrent clairement jusqu'à quel point la Charte a modifié le pouvoir. Avant son adoption, les tribunaux auraient été liés par les termes de la législation des droits de la personne et leur rôle aurait consisté à voir à ce que cette législation soit respectée. Ils ont maintenant le pouvoir de tester la validité de la législation par rapport aux droits et libertés énoncés dans la Charte. Dans beaucoup de domaines, particulièrement en droit criminel et dans le contrôle des activités des bureaucrates gouvernementaux, les tribunaux ont vite trouvé des violations de la Charte, annulé la législation et les règlements, ou surveillé la conduite des bureaucrates.

Il est intéressant de noter qu'en dépit de la Charte, les deux décisions touchant la retraite obligatoire révèlent quelque restriction judiciaire de la disposition de s'en remettre aux politiques législatives. En fait, le cas de la Colombie britannique le fait clairement remarquer. Selon le tribunal, la nouvelle Constitution n'investissait pas les tribunaux du pouvoir de promouvoir ou contrôler les changements économiques et sociaux. On se rappellera le débat sur l'opportunité d'inclure dans la Charte une disposition sur la protection de la propriété privée. L'un des arguments contre une telle disposition était qu'aux Etats-Unis au moins, on avait utilisé cette clause à un moment donné pour annuler une grande partie de la législation relative à la sécurité sociale et à l'emploi. Il est par conséquent possible que les tribunaux canadiens, même s'ils n'hésitent pas à utiliser la Charte pour protéger les individus contre l'Etat, laissent au Parlement et aux législatures le soin de s'occuper des politiques économiques et sociales.

Deuxièmement, en considérant particulièrement les universités, s'il était finalement décidé que la retraite obligatoire est en fait inconstitutionnelle, les universités et les professeurs, de même que les autres employeurs et employés, devront s'ajuster à ce nouveau contexte. L'ajustement dépendra dans une certaine mesure du nombre de personnes qui continuent à travailler après 65 ans, et pendant combien de temps.

Il semble prématuré d'essayer de tirer des conclusions claires de l'expérience des organismes où la retraite obligatoire a été abolie. Néanmoins, on a de bonnes raisons de croire qu'un nombre important de personnes travailleront jusqu'à la fin de la soixantaine. 
S'il en est ainsi, cette situation posera des problèmes, au moins à court terme. Les professeurs qui continueront à travailler après 65 ans alourdiront les dépenses salariales des universités et pourront entraîner des complications eu égard aux plans de retraite et aux autres avantages économiques. L'influx de nouveaux professeurs pourrait être retardé, à moins qu'il n'y ait en même temps un influx d'argent pour les salaires. On soulèvera sans aucun doute la question de la permanence car on pourra soutenir alors que sans la retraite obligatoire, c'est un système de permanence à vie ou du moins jusqu'à la retraite volontaire qui prévaudra.

Les universités peuvent réagir de plusieurs façons. En ce qui concerne la permanence, il serait possible d'évaluer la performance plus rigoureusement et plus régulièrement. Cependant, si on adopte largement ces mécanismes d'évaluations, et si de plus, on les combine aux autres processus de promotion et de permanence longs et compliqués, on peut se demander s'il restera du temps pour l'entreprise d'éducation elle-même. Il est facile d'imaginer tout un éventail de questions de procédure et de droit positif qu'il faudrait affronter. Dans le contexte de la Charte, on peut même se demander si le processus d'évaluation du rendement déclenché à un certain âge constituerait en soi une violation de la Charte.

Peut-être, qu'au lieu de s'engager dans des évaluations du rendement sur une plus grande échelle que ce qui est en vigueur actuellement, les universités feraientelle mieux d'essayer d'adopter des pratiques qui en fait, accommoderaient les attentes et les buts des professeurs. Certains professeurs peuvent bien sûr souhaiter travailler après 65 ans. Cependant, il y a aussi ceux qui souhaitent prendre leur retraite avant cet âge si le sacrifice financier n'est pas trop grand. Il y en a d'autres également qui aimeraient changer du statut de professeur à temps plein à celui de professeur à temps partiel avant l'âge traditionnel de la retraite, et peut-être travailler à temps partiel quelques années après. Même si en fin de compte, on n'a pas dit que la disposition touchant la retraite obligatoire était invalide, les universités doivent commencer à étudier et mettre en pratique les points ci-dessus ; un bon nombre d'entre elles se sont d'ailleurs déjà mises à l'oeuvre. Cependant, pour des raisons internes et externes, ces changements ne pourront peut-être pas se faire facilement. Par exemple, il semble que les changements à la loi de l'impôt qui sont actuellement à l'étude limitent les versements dans un fonds de pension pour le compte de ceux qui ont le statut d'employé à temps partiel et font ainsi de cette option un choix moins attrayant.

La décision concernant les deux cas qui ont fait l'objet de notre propos peut dans une certaine mesure révéler jusqu'à quel point les tribunaux sont prêts à utiliser leurs pouvoirs prévus à la Charte dans le domaine socio-économique. Quelle que soit la décision, le débat sur la retraite obligatoire amènera peut-être les universités (et d'autres employeurs) à considérer des pratiques flexibles, particulièrement en ce qui touche les employés qui approchent de ce qui était jusqu'à maintenant l'âge normal de retraite. 